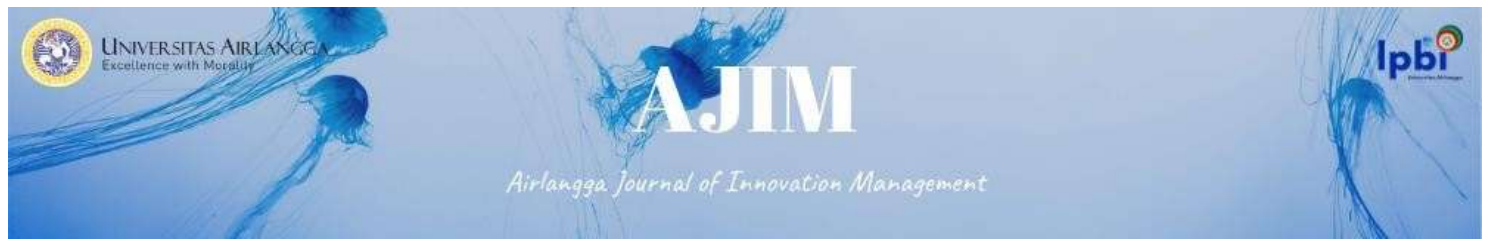

Vol. 1 No.2 Oktober 2020

e-ISSN: 2722-5062

DOI : 10.20473/ajim.v1i1.21906

\title{
ANALYSIS OF EMOTIONAL INTELLIGENCE AND WORK DISCIPLINE ON EMPLOYEE PERFORMANCE WITH ORGANIZATIONAL COMMITMENT AS AN INTERVENING VARIABLE
}

\author{
Nashrudin Setiawan ${ }^{1}$, Renny Maisyarah ${ }^{2}$, Rosina Harahap ${ }^{3}$ \\ Universitas Pembangunan Panca Budi ${ }^{12}$ \\ Universitas Graha Nusantara ${ }^{3}$ \\ Correspondent e-mail: $\underline{\text { snashrudin@gmail.com }}{ }^{1}$
}

\begin{abstract}
ABSTRAK
This study aims to determine whether emotional intelligence partially has a positive and significant effect on employee performance at PT JTI. This research tries to answer a) Does work discipline partially have a positive and significant effect on employee performance at PT JTI; b)Does emotional intelligence affect employee performance through an organizational commitment to PT JTI; and c) Does work discipline affect employee performance through an organizational commitment to PT JTI. The data analysis technique used is the associative method with SPSS version 16.0 program. This study uses the classic assumption test, multiple linear regression analysis, $t$-test, $F$ test, determination test and path analysis test. The population in this study were all employees of PT JTI and a sample of 60 respondents which the primary data were taken using a questionnaire. The results showed that emotional intelligence partially had a positive and significant effect on employee performance at PT JTI.
\end{abstract}

Keywords: Emotional Intelligence, Work Discipline, Organizational Commitment and Employee Performance

\begin{abstract}
ABSTRAK
Penelitian ini bertujuan untuk mengetahui apakah kecerdasan emosional secara parsial berpengaruh positif dan signifikan terhadap kinerja karyawan pada PT JTI. Penelitian ini mencoba menjawab a) Apakah disiplin kerja secara parsial berpengaruh positif dan signifikan terhadap kinerja karyawan pada PT JTI; b) Apakah kecerdasan emosional mempengaruhi kinerja karyawan melalui komitmen organisasi pada PT JTI; dan c) Apakah disiplin kerja berpengaruh terhadap kinerja karyawan melalui komitmen organisasi pada PT JTI. Teknik analisis data yang digunakan adalah metode asosiatif dengan program SPSS versi 16.0. Penelitian ini menggunakan uji asumsi klasik, analisis regresi linier berganda, uji $t$, uji $F$, uji determinasi dan uji analisis jalur. Populasi dalam penelitian ini adalah seluruh karyawan PT JTI, dan sampel sebanyak 60 responden yang pengambilan data primernya menggunakan kuesioner. Hasil penelitian menunjukkan bahwa kecerdasan emosional secara parsial berpengaruh positif dan signifikan terhadap kinerja karyawan pada PT JTI.
\end{abstract}

Kata Kunci: Kecerdasan Emosional, Disiplin Kerja, Komitmen Organisasi dan Kinerja karyawan

\section{INTRODUCTION}

The era of globalization requires companies to make decisions in the right strategy so that they can compete in an increasingly fierce and competitive industrial environment - especially decisions in the functional field. One the things that must be considered in management functions is how to manage human resources in order to increase work efficiency and effectiveness so that the company organization will continue to exist and be able to win the competition. A company or organization must have qualified or superior human resources so that the existence of other resources can provide optimal benefits for the achievement of company goals. The success and performance of the company can be seen from the performance achieved by its employees, 


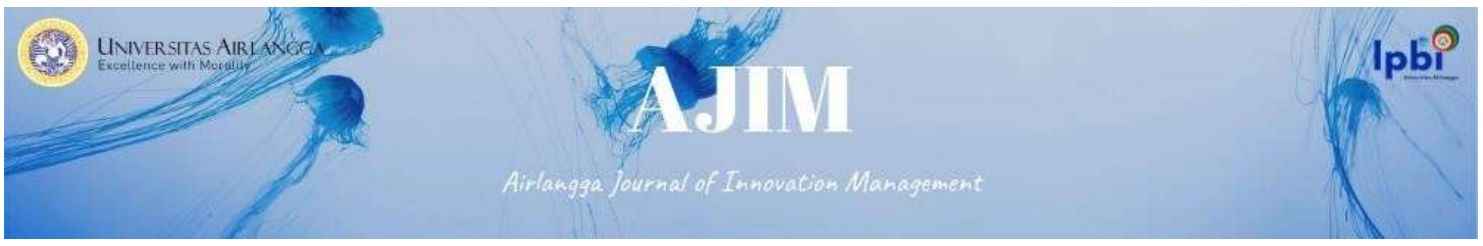

PT JTI is one of the companies engaged in Mechanical \& Electrical Contractors, with a vision to become a leading company that integrates Trading, Operation and Maintenance Services in Mechanical Electrical field. Some factors affect the performance of PT JTI employees, namely emotional intelligence, work discipline and organizational commitment.

According to Goleman (2014: 75), employees who have high emotional intelligence will produce a better performance which can be seen from quality and quantity given to the company by these employees. Goleman (2014: 76) also revealed that even if someone has a pretty good performance, if he has a closed nature and does not interact well with other people, his performance will not be able to develop. Goleman (2014: 80) suggests three basic skills in emotional intelligence, namely selfawareness, self-control and empathy (social awareness).

Based on the pre-survey, there is a problem with emotional intelligence among employees of PT JTI in table 1 as follows:

Table 1. Pre-Survey Results Regarding Emotional Intelligence of PT JTI Employees

\begin{tabular}{|l|l|l|l|l|l|l|}
\hline \multicolumn{2}{|c|}{ Statement } & \multicolumn{2}{|c|}{ Yes } & \multicolumn{2}{|c|}{ Not } & \multicolumn{2}{c|}{ Total } \\
\cline { 2 - 7 } & Person & $\mathbf{( \% )}$ & Person & $\mathbf{( \% )}$ & Person & (\%) \\
\hline $\begin{array}{l}\text { I am a person who is confident in } \\
\text { working. }\end{array}$ & 9 & $30.00 \%$ & 21 & $70.00 \%$ & 30 & $100 \%$ \\
\hline $\begin{array}{l}\text { I can control myself in any condition } \\
\text { when doing work. }\end{array}$ & 6 & $20.00 \%$ & 24 & $80.00 \%$ & 30 & $100 \%$ \\
\hline $\begin{array}{l}\text { I can accept and understand the } \\
\text { organization point of view. }\end{array}$ & 8 & $26.67 \%$ & 22 & $73.33 \%$ & 30 & $100 \%$ \\
\hline
\end{tabular}

Source: Data processed (2020)

Based on table 1 above, it can be seen about the emotional intelligence statement of PT JTI, where the dimensions of self-awareness that is, employees are not confident in carrying out their work. Dimensionsself-control, i.e. employees are not able to control themselves in any condition when doing work. Dimensions empathy (social awareness), i.e. employees are not able to accept and understand the point of view of the organization.

The implementation of discipline in a company is a must because discipline is used as a rule or guideline in managing company management. According to Rivai (2013: 825), discipline is "a tool used by managers to communicate with employees so that they are willing to change behaviour as well as an effort to increase one's awareness and willingness to obey all applicable social rules and norms. Work discipline is one of the factors that affect the level of performance possessed by employees. Employee compliance in implementing work discipline will help improve employee performance in carrying out work discipline and ensure the company's operations are well and smoothly carried out. According to Rivai (2013: 827), "indicators of work discipline have obeyed the rules of time, obey the rules of the organization/agency and obeying the rules of conduct at work".

Based on the pre-survey, there are work discipline problems for PT JTI employees in table 2 as follows:

Table 2 Pre-Survey Results Regarding Work Discipline for Employees of PT JTI

\begin{tabular}{|l|l|l|l|l|l|l|}
\hline \multicolumn{1}{|c|}{ Statement } & \multicolumn{2}{c|}{ Yes } & \multicolumn{2}{c|}{ Not } & \multicolumn{2}{c|}{ Total } \\
\cline { 2 - 7 } & Person & $\mathbf{( \% )}$ & Person & $\mathbf{( \% )}$ & Person & $\mathbf{( \% )}$ \\
\hline $\begin{array}{l}\text { I always come on time, according } \\
\text { to the schedule set. }\end{array}$ & 13 & $43.34 \%$ & 17 & $56.66 \%$ & 30 & $100 \%$ \\
\hline I work under the main task given. & 14 & $46.67 \%$ & 16 & $53.33 \%$ & 30 & $100 \%$ \\
\hline $\begin{array}{l}\text { I complete the task according to } \\
\text { the procedure. }\end{array}$ & 12 & $40.00 \%$ & 18 & $60.00 \%$ & 30 & $100 \%$ \\
\hline
\end{tabular}

Source: Data processed (2020) 


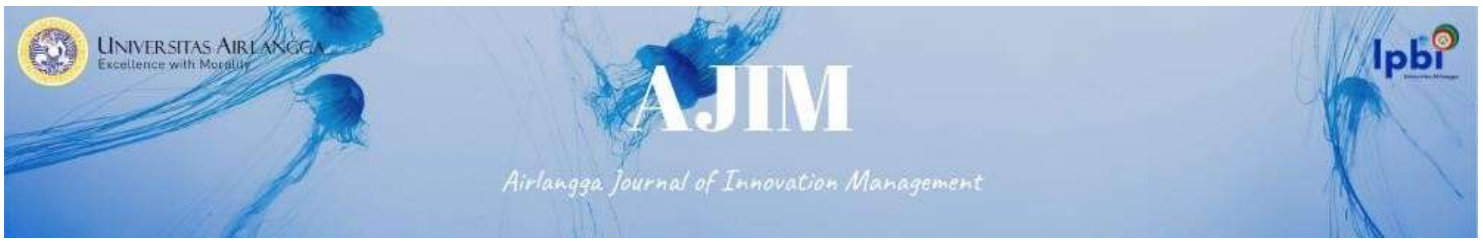

Based on table 2 above, it can be seen about the work discipline statement of PT JTI where the dimensions obey the rules of time that is; there are still employees who are not on time. Dimensions obey the rules of the organization/agency that is, sometimes the work that the employee does is not under the main task given. Dimensions are obeying the rules of conduct at work that is, sometimes the work that the employee does is not under the procedure.

According to Griffin (2014: 17), a person's commitment to their profession and the organization where they work is often a very important issue. Commitment to work in the company is inseparable from the form of relationship between the employee and the job or profession where the employee works in order to achieve the business goals desired by the company. Organizational commitment can affect employee performance by having a high commitment; an employee will carry out his duties or work in an orderly and smooth manner so that his work results (performance) will increase and will also have an impact on company goals that can be achieved optimally. According to Griffin (2014: 23), indicators of organizational commitment are effective commitment, ongoing commitment and normative commitment.

Based on the pre-survey, there is a problem of organizational commitment at PT JTI in table 3 as follows:

Table 3 Pre-Survey Results Regarding Organizational Commitment at PT JTI

\begin{tabular}{|l|l|l|l|l|l|l|}
\hline \multicolumn{2}{|c|}{ Statement } & \multicolumn{2}{c|}{ Yes } & \multicolumn{2}{c|}{ Not } & \multicolumn{2}{c|}{ Total } \\
\cline { 2 - 7 } & Person & $\mathbf{( \% )}$ & $\begin{array}{l}\text { Perce } \\
\text { ntage }\end{array}$ & $\mathbf{( \% )}$ & Person & $\mathbf{( \% )}$ \\
\hline $\begin{array}{l}\text { I always participate in company } \\
\text { activities. }\end{array}$ & 10 & $33.34 \%$ & 20 & $66.66 \%$ & 30 & $100 \%$ \\
\hline $\begin{array}{l}\text { I have a strong sense of } \\
\text { belonging to the company. }\end{array}$ & 12 & $40.00 \%$ & 18 & $60.00 \%$ & 30 & $100 \%$ \\
\hline $\begin{array}{l}\text { I have a sense of responsibility } \\
\text { to stay in an organization. }\end{array}$ & 11 & $36.67 \%$ & 19 & $63.33 \%$ & 30 & $100 \%$ \\
\hline
\end{tabular}

Source: Data processed (2020)

Based on table 3 above, it can be seen about the statement of organizational commitment of PT JTI where the commitment dimension is effective, i.e. employees do not participate in company activities. Dimensionsongoing commitment, i.e. employees do not have a strong sense of belonging to the company. Dimensionsnormative commitment, i.e. employees do not have a sense of responsibility to stay in an organization.

\section{LITERATURE REVIEW}

\section{A. Emotional Intelligence}

According to Goleman (2014: 65), the person who first revealed the existence of intelligence other than academics that can affect a person's success is called emotional intelligence. According to Goleman (2014: 66), emotional intelligence is "the ability to use emotions effectively in managing oneself and positively influencing relationships with others. Emotional intelligence includes the ability to control ourself, stimulate, remain diligent, and can motivate ourself. These skills include managing emotional forms, both positive and negative.

Hasibuan (2015: 25) argues that: emotional intelligence is the ability in the field of emotions, namely the ability to face frustration, the ability to control emotions, the spirit of optimism, and the ability to have relationships with other people or empathy. According to Mangkunegara (2015: 34), emotional intelligence is a person's ability to accept, assess, manage, and control the emotions of himself and others around him. In this case, emotion refers to feelings of information about a relationship. 


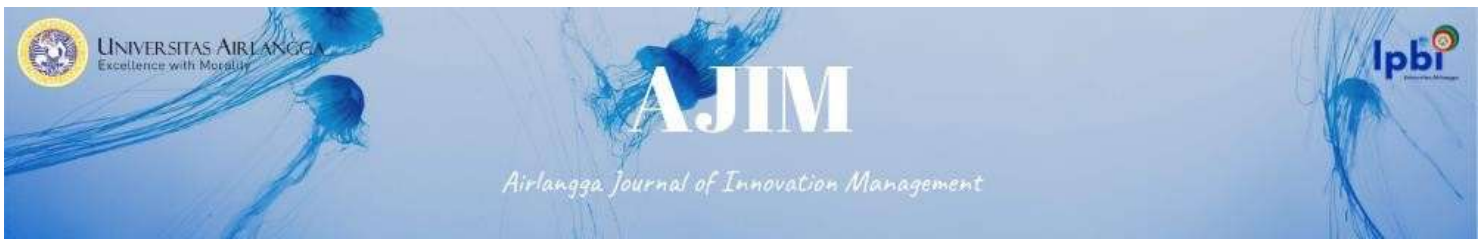

\section{B. Work Discipline}

In everyday life, many interpret discipline as the obedience of a person or group of predetermined rules. In the world of work, discipline is the awareness and willingness of a person to obey all company regulations and prevailing social norms. According to Rivai (2013: 825), work discipline is "a tool used by managers to communicate with employees so that they are willing to change a behavior and as an effort to increase one's awareness and willingness to obey all applicable social rules and norms".

According to Hasibuan (2015: 194), work discipline can be defined as an attitude of respect, respect, obedience and obedience to the prevailing regulations, both written and unwritten. According toSutrisno (2015: 91), work discipline is a mental attitude that is reflected in the actions or behaviour of individuals, groups, or society in the form of obedience to the rules set for a specific purpose. According to Rivai (2013: 826), "the following are the benchmarks for employee discipline are:

1) Attitudes are the mental and behaviour of employees that come from their awareness or willingness to carry out their duties and company regulations.

2) Responsibility is the ability to carry out company duties and regulations.

3) Norms are the ability of employees to fully understand the applicable regulations as a reference in behaving and knowing the purpose and benefits of these regulations.

According to Rivai (2013: 831), the imposition of sanctions for disciplinary violations must not discriminate between employees, young and old, male and female, still enforced the same under applicable regulations. The goal is for employees to realize that work discipline applies to all employees with sanctions for violations under the applicable regulations in the company. In general, as a manager's grip, although not absolute, the level and type of work discipline consist of severe disciplinary sanctions, moderate disciplinary sanctions and mild disciplinary sanctions.

\section{Organizational Commitment}

Organizational commitment is most often defined as a strong desire to remain a member of a particular organization, a desire to strive according to the wishes of the organization, certain beliefs, and acceptance of the organization's values and goals. In other words, this is an attitude that reflects employee loyalty to the organization and a continuous process in which organizational members express their concern for the organization and its continued success and progress. Mathis (2013: 75) states that "organizational commitment is the nature of an individual's relationship with an organization by showing the following characteristics":

1) Accept organizational values and goals.

2) Have a desire to do for the organization.

Griffin (2014: 15) states that organizational commitment is an attitude that reflects the extent to which an individual knows and is tied to the organization. Those employees who feel more committed to the organization have reliable habits, plan to stay longer in the organization, and put more effort into their work". According to Robbins (2014: 140), organizational commitment is a condition in which an employee sides with a particular organization and its goals, and intends to maintain membership in that organization. So, organizational commitment is an active relationship orientation between individuals and their organizations. This relationship orientation results in the individual (employee) willing to give something,

\section{Employee performance}

Performance is a universal concept which is the operational effectiveness of an organization, part of the organization, and its employees based on predetermined standards and criteria. Humans run organizations, so performance is human behaviour in playing that role they do in an organization to meet the standards of behaviour that have been set in order to produce the desired results and actions. According to Mangkunegara (2015: 97) "performance is a person's success in carrying out a job and this performance is basically the result of an employee's work for a certain period". 


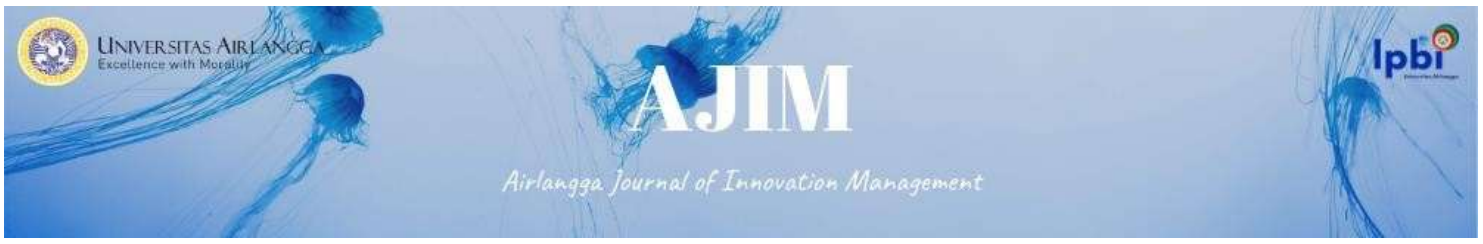

Robbins (2014: 46) provides another definition of performance, namely" performance is a comparison between the actual work results with the work standards set and the performance itself is more focused on the results of the work. Meanwhile, according to Mathis (2013: 151), employee performance is what the employee does and what is not done. Employee performance affects how much they contribute to the organization.

Mathis (2013: 153) suggests that the factors that affect performance can be grouped into two, namely intrinsic factors and extrinsic factors. Intrinsic factors include motivation, education, abilities, skills and knowledge, all of which can be obtained from training. Extrinsic factors include work environment, leadership, work relationship and salary.

\section{E. Conceptual Framework}

According to Goleman (2014: 75), employees who have high emotional intelligence will produce a better performance which can be seen from the quality and quantity given to the company by these employees. Goleman (2014: 76) also revealed that even if someone has a pretty good performance, if he has a closed nature and does not interact well with other people, his performance will not be able to develop.

The implementation of discipline in a company is a must because discipline is used as a rule or guideline in managing company management. According to Rivai (2013: 825), a discipline is a tool used by managers to communicate with employees so that they are willing to change behaviour and as an effort to increase one's awareness and willingness to obey all applicable social rules and norms. Discipline looks at how employee compliance is to be able to obey, and orderly carry out existing rules, assess knowledge of applicable regulations, and self-awareness. The discipline itself is one of the factors that affect the level of performance possessed by employees.

According to Griffin (2014: 17), a person's commitment to their profession and the organization they work for is often a very important issue. Organizational commitment can affect employee performance by having a high commitment; an employee will carry out his duties or work in an orderly and smooth manner so that his work results (performance) will increase and will also have an impact on company goals that can be achieved optimally.

Based on the research title and the problems previously described, the conceptual framework of this study is described as follows:

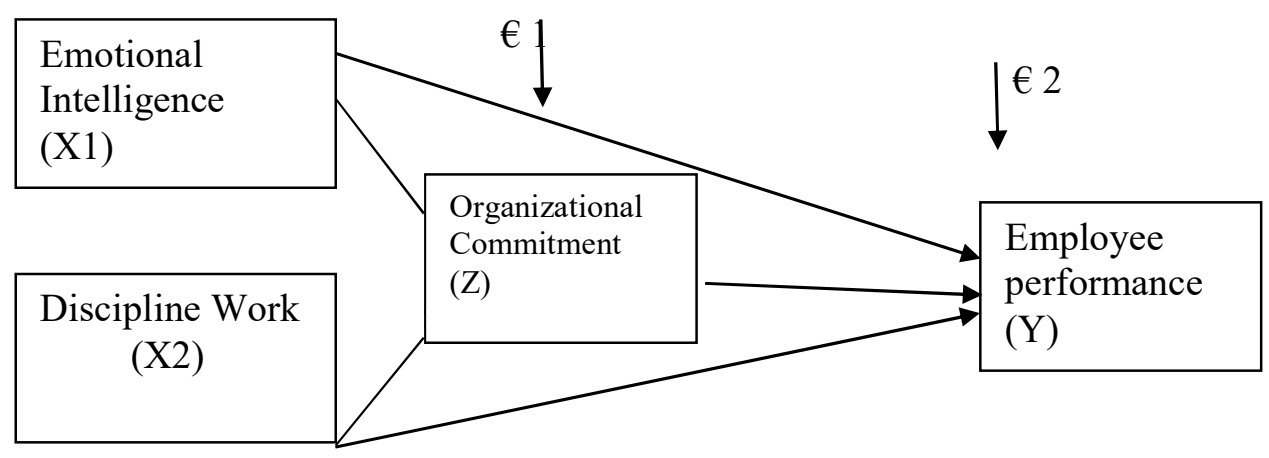

Figure 1 Conceptual Framework

Source: Data processed (2020) 


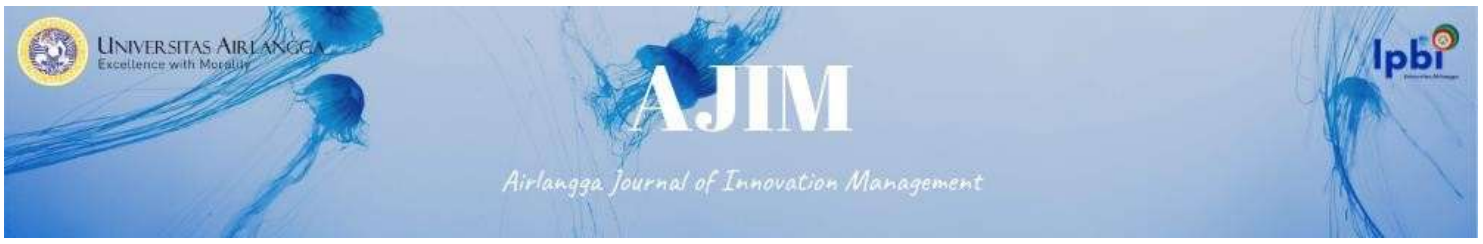

\section{Hypothesis}

The hypothesis is a statement or accusation that while research problems are still weak (not necessarily true), they must be tested empirically. Based on the above thought, the authors propose the following hypothesis:

1. Suspected partial emotional intelligence positive and significant effect on employee performance at PT JTI.

2. Presumably, work discipline partially positive and significant effect on employee performance at PT JTI.

3. Suspected emotional intelligence take effect on employee performance with through organizational commitment at PT JTI.

4. Presumably, work discipline takes effect on employee performance with through organizational commitment at PT JTI.

\section{METHODOLOGY}

A. Research Approach

The research approach used is associative research. Research associative is a type of research that has multiple variables, a single object, and a pattern of relationship or influence between the independent variable on the dependent variable.

\section{B. Operational Definition of Variables}

1) Research variable

Research variables include what variables will be studied. This study uses 2 (two) exogenous variables, namely: emotional intelligence (X1) and work discipline (X2), 1 (one) intervening variable, namely organizational commitment (Z), and 1 (one) endogenous variable, namely employee performance (Y).

2) Operational definition

The operational definition is an indication of how a variable is measured operationally in the field.

\section{Population and Sample / Types and Sources of Data}

\section{Population}

According to Sugiyono (2016: 72), the research population is all elements/elements that will be observed or researched. The population in this study were all 60 employees of PT JTI.

\section{Sample}

According to Sugiyono (2016: 73), the sample is part of the number and characteristics of the population. In this study, the authors performed a non-probability sampling technique using census sampling or saturated sampling because the entire population was sampled if the population was below 100. Therefore, the sample in this study was 60 employees./ respondent ".

\section{Table 4 Research Samples}

\begin{tabular}{|l|l|c|}
\hline o. & Position & $\begin{array}{c}\text { Number of } \\
\text { Employees }\end{array}$ \\
\hline & Manager & 1 \\
\hline & Admin & 2 \\
\hline & Shift Leader & 3 \\
\hline & Operational Supervisor & 4 \\
\hline & Supervisor Project & 5 \\
\hline & Operator & 45 \\
\hline & Total & $\mathbf{6 0}$ \\
\hline
\end{tabular}

Source: Data processed (2020) 


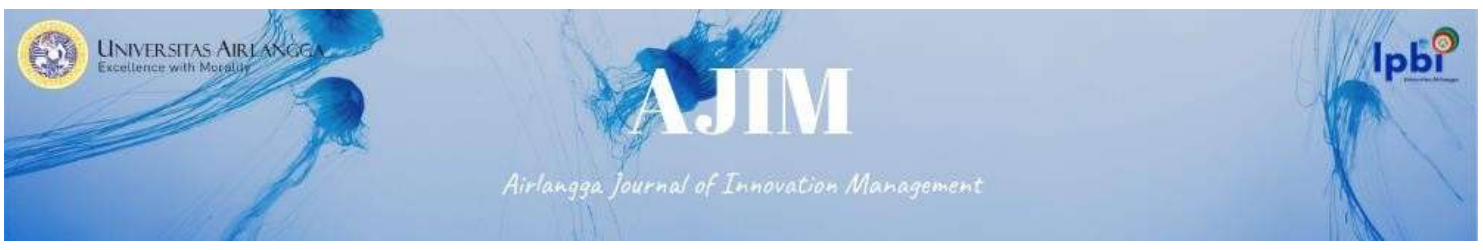

\section{Type of Data}

Primary data is data obtained directly from respondents at the research location. Primary data were obtained using a questionnaire list and direct interviews with employees of PT JTI.

\section{Data source}

Sources of data in this study are employees of PT JTI.

\section{E. Data collection technique}

According to Sugiyono (2016: 75), to obtain the data needed in order to analyze proving provisional answers or hypotheses to the problems raised, the data collection method that the author uses is a questionnaire method, which is distributing questionnaires to be filled out by employees.

\section{F. Data analysis technique}

\section{Data Quality Test}

Before the data is analyzed and evaluated, the data is first tested by:

a. Validity test

According to Sugiyono (2016: 76), to get quality and good quality research results, a series of studies should be done well. The validity test is conducted to measure whether the data that has been obtained after the study is valid data with the measuring instrument used (questionnaire). The validity test of each question is greater $(>) 0.30$, so the question items are considered valid.

b. Reliability Test (reliability)

According to Sugiyono (2016: 76), reliability is the level of reliability of a research instrument. A reliable instrument is an instrument that when used repeatedly to measure the same object, will produce the same data. The reliability test will be able to show the consistency of the respondent's answers in the questionnaire. Reliability test is done by testing the statement items that have been declared valid in the validity test, and the reliability will be determined. The reliability of a variable construct is said to be good if it has a Cronbach's alpha value greater $(>)$ 0.60 .

\section{1) Classic assumption test}

The classic assumption test is used to see or test a model that is feasible or not used in research. The classic assumption tests used in this study are:

a. Normality test

The purpose of the normality test is to find out whether the distribution of a data follows or is close to the normal distribution, namely the data distribution in the shape of a bell. Good data is data that has a pattern like a normal distribution, that is, the distribution of the data does not tilt to the left or tilt to the right (Sugiyono, 2016: 81). To test this, a graphical method can be used. Normal PP Plot of standardized residual cumulative probability, by identifying if it is actually around the normal line, then the assumption of normality can be fulfilled. The KolmogorovSmirnov test is also used to see normality by identifying that the P-value is greater than alpha, so the assumption of normality can be accepted. By using a significance level of $5 \%(0.05)$, then if the value is Asymp.

b. Multicollinearity Test

According to Sugiyono (2016: 82), multicollinearity test aims to test whether the regression model found a correlation between independent variables (independent). A good regression model should not correlate with the independent variables. Tolerance measures the variability of the selected variable that is not explained by other independent variables. The general values that can be used are Tolerance $>0.1$ or $\mathrm{VIF}<10$, so there is no multicollinearity.

c. Heteroscedasticity Test

According to Sugiyono (2016: 83), the variance of the independent variable is constant for each specific value of the independent variable (homoscedasticity). A good regression model does not occur heteroscedasticity. The basis for decision making is that if a certain pattern, such as points (points), forms a certain regular pattern, then heteroscedasticity occurs. If there is no clear 


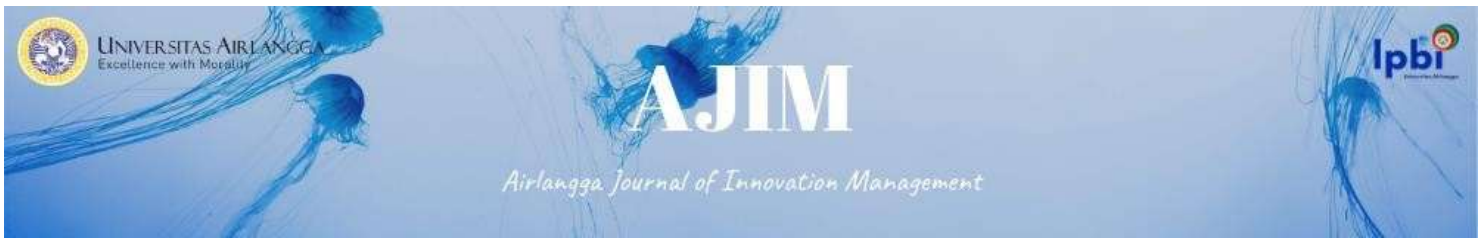

pattern, and the dots (points) spread below and above the 0 on the $\mathrm{Y}$ axis, there will be no heteroscedasticity".

\section{2) Hypothesis testing}

a. Simultaneous Test (Test F)

The $\mathrm{F}$ test is used to test whether the independent variables have a simultaneous influence on the dependent variable. To analyze whether the hypothesis is accepted or rejected, it can be seen that the $\mathrm{F}$ value is the probability value. The hypothesis is:

H0: there is an insignificant effect

Ha: there is a significant effect.

The criteria for acceptance/rejection of the hypothesis are as follows:

1) Reject $\mathrm{H} 0$ if the calculated probability value $<$ applied probability is 0.05 ( $\mathrm{Sig}<\alpha 0.05)$.

2) Accept $\mathrm{H} 0$ if the calculated probability value $>$ the set probability of $0.05(\mathrm{Sig}>\alpha 0.05)$

b. Partial test (t-test)

The t-test is used to test the hypothesis when the researcher analyzes partial regression (an independent variable with a dependent variable). Then this test can be seen from the probability value. The hypothesis is:

$\mathrm{H} 0$ : there is an insignificant effect

Ha: there is a significant effect.

The criteria for acceptance/rejection of the hypothesis are as follows:

1) Reject $\mathrm{H} 0$ if the calculated probability value is $<$ significance level of 0.05 ( $\mathrm{Sig}<\alpha 0.05$ ).

2) Accept $\mathrm{H} 0$ if the calculated probability value $>$ the significance level of 0.05 ( $\mathrm{Sig}>\alpha$ $0.05)$.

c. Coefficient of Determination $\left(\mathrm{R}^{2}\right)$

According to Sugiyono (2016: 84), the coefficient of determination or R-square (R2) is to see how variations influence variations in the value of the dependent variable in the value of the independent variable. The small value of $\mathrm{R} 2$ means that the ability of the independent variables to explain the variation in the dependent variable is very limited. A value close to one means that the independent variables provide almost all the information needed to predict the variation in the dependent variable.

\section{3) Path Analysis}

The path analysis method is a method that examines the direct or indirect effect (effect) of the hypothesized variables as a result of the effect of treatment on these variables (Sudaryono, 2013: 392). In the path diagram, it can be seen that there are direct and indirect effects from one variable to another. If there is a causal relationship between two variables, it must first be determined the direction of the relationship. The determination of the direction of this causal relationship is made based on existing theory and knowledge (Sudaryono, 2013: 393).

The path diagram illustrating the pattern of the relationship between variables in this study is a test to test and find out how much influence emotional intelligence and work discipline has on employee performance with organizational commitment as an intervening variable with the equation:

$$
\begin{array}{|ll|}
\hline & \begin{array}{l}
\text { Equation I: } \mathrm{Z}=\mathrm{P} 1 \mathrm{X} 1+\mathrm{P} 1 \mathrm{X} 2+€ 1 \\
\text { Equation II: } \mathrm{Y}=\mathrm{P} 3 \mathrm{X} 1+\mathrm{P} 3 \mathrm{X} 2+\mathrm{P} 2 \mathrm{Z}+€ 2
\end{array} \\
\text { Information: } & \\
\mathrm{X} 1 & =\text { Emotional Intelligence (Exogenous Variable) } \\
\mathrm{X} 2 & =\text { Work Discipline (Exogenous Variable) } \\
\mathrm{Z} & =\text { Organizational Commitment (Intervening Variable) } \\
\mathrm{Y} & =\text { Employee Performance (Endogenous Variable) } \\
\mathrm{P} & =\text { Path Regression Coefficient } \\
€ & =\text { Number of variants }(€=1-\mathrm{R} 2)
\end{array}
$$




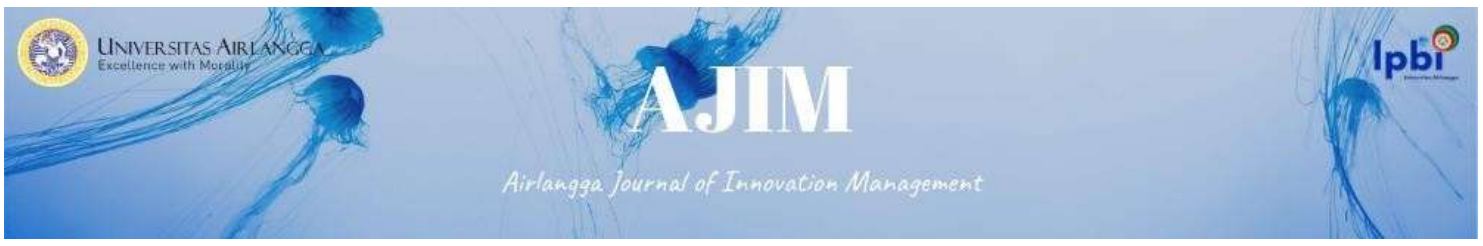

4) Mediation Test

To see whether the organizational commitment is a variable that mediates between emotional intelligence and work discipline on employee performance by using standardized beta coefficients which are standardized with the following conditions:

- $\quad$ P3 $>$ P1 x P2, meaning that organizational commitment is not a variable that mediates between emotional intelligence and work discipline on employee performance.

- $\mathrm{P} 3<\mathrm{P} 1 \times \mathrm{x} 2$, meaning that organizational commitment becomes a variable that mediates between emotional intelligence and work discipline on employee performance.

Mediation testing with the decision effect criteria (KPK) is:

- Accept Ho (reject Ha), if P3> P1 x P2.

- Reject Ho (accept Ha), if P3 $<$ P1 x P2

The mediation test shows whether emotional intelligence and work discipline have a direct effect on employee performance. While the magnitude of the indirect effect (indirect effect) where emotional intelligence and work discipline affect employee performance through organizational commitment.

\section{RESULT AND DISCUSSION}

\section{A. Research result}

\section{Description of Respondent Characteristics}

The characteristics of the respondents described below reflect how the respondents studied included gender, age, last education and years of service.

a. Characteristics of Respondents Based on Gender.

\begin{tabular}{|lc|r|r|r|l|}
\hline & & & \multicolumn{2}{|c|}{ Gender } \\
\hline & Frequency & Percent & Valid Percent & $\begin{array}{l}\text { Cumulative } \\
\text { Percent }\end{array}$ \\
\hline Valid & Male & 34 & 56.7 & 56.7 & 56.7 \\
& Women & 26 & 43.3 & 43.3 & 100.0 \\
& Total & 60 & 100.0 & 100.0 & \\
\hline
\end{tabular}

Source: Data processed (2020)

\section{Validity and Reliability Testing}

\section{a. Validity Testing}

To determine the feasibility of the items in the questionnaire that have been presented to the respondent, it is necessary to test the validity. If the validity of each question is greater $(>) 0.30$, then the question items are considered valid. 


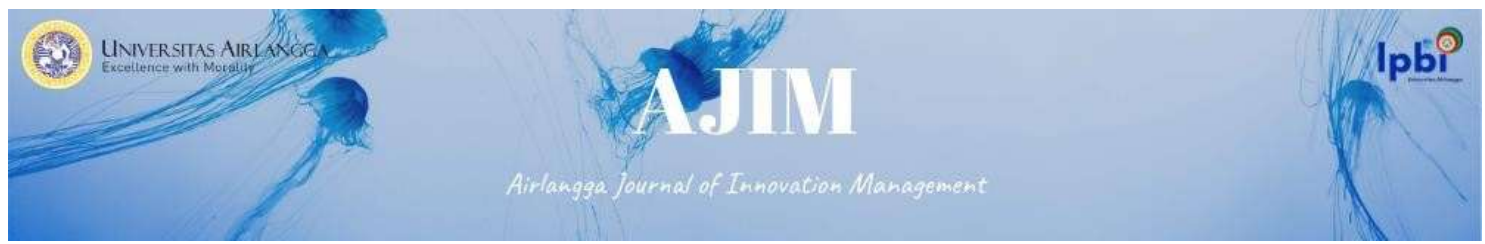

Table 5 Validity Test (X1) Emotional Intelligence

Item-Total Statistics

\begin{tabular}{|l|r|r|r|r|}
\hline & $\begin{array}{c}\text { Scale Mean if } \\
\text { Item Deleted }\end{array}$ & $\begin{array}{c}\text { Scale Variance if } \\
\text { Item Deleted }\end{array}$ & $\begin{array}{c}\text { Corrected Item- } \\
\text { Total } \\
\text { Correlation }\end{array}$ & $\begin{array}{c}\text { Cronbach's Alpha } \\
\text { if Item Deleted }\end{array}$ \\
\hline Statement X1.1 & 26.8667 & 19,948 & $\mathbf{. 4 5 1}$ & .822 \\
Statement X1.2 & 27,0500 & 19,845 & $\mathbf{. 5 8 5}$ & .802 \\
Statement X1.3 & 26,9833 & 20,084 & $\mathbf{. 5 7 9}$ & .803 \\
Statement X1.4 & 26.8833 & 19,935 & $\mathbf{. 5 1 0}$ & .812 \\
Statement X1.5 & 27,2000 & 20,536 & $\mathbf{. 6 3 4}$ & .799 \\
Statement X1.6 & 27,2000 & 20,536 & $\mathbf{. 6 3 4}$ & .799 \\
Statement X1.7 & 27,2000 & 20,536 & $\mathbf{. 6 3 4}$ & .799 \\
Statement X1.8 & 27.0667 & 21,046 & $\mathbf{. 4 6 7}$ & .816 \\
Statement X1.9 & 27.0167 & 21,847 & $\mathbf{. 3 6 5}$ & .827 \\
\hline
\end{tabular}

Source: Data processed (2020)

From table 5 above the results of the SPSS output, it is known that the validity value is in the Corrected item-total Correlation column, which means that the correlation value between the score of each item and the total score on the tabulation of the respondent's answer. The results of the validity test of 9 (nine) question items on the emotional intelligence variable can be declared valid (valid) because all coefficient values are greater than 0.30 .

Table 6 Validity Test (X2) Work Discipline

Item-Total Statistics

\begin{tabular}{|l|r|r|r|r|}
\hline & $\begin{array}{c}\text { Scale } \\
\text { Mean if Item } \\
\text { Deleted }\end{array}$ & $\begin{array}{c}\text { Scale } \\
\text { Variance if Item } \\
\text { Deleted }\end{array}$ & $\begin{array}{c}\text { Correcte } \\
\text { d Item-Total } \\
\text { Correlation }\end{array}$ & $\begin{array}{c}\text { Cronbach' } \\
\text { s Alpha if Item } \\
\text { Deleted }\end{array}$ \\
\hline Statement X2.1 & 27.0667 & 25,758 & $\mathbf{. 4 6 8}$ & .872 \\
Statement X2.2 & 26,7333 & 22,809 & $\mathbf{. 8 0 0}$ & .843 \\
Statement X2.3 & 26,8500 & 25,757 & $\mathbf{. 4 7 2}$ & .872 \\
Statement X2.4 & 26.8667 & 23,914 & $\mathbf{. 5 2 7}$ & .870 \\
Statement X2.5 & 26,9500 & 25,540 & $\mathbf{. 4 9 1}$ & .870 \\
Statement X2.6 & 26.7667 & 23,165 & $\mathbf{. 7 7 7}$ & .846 \\
Statement X2.7 & 26.5833 & 22,654 & $\mathbf{. 6 7 4}$ & .855 \\
Statement X2.8 & 26.7833 & 24,579 & $\mathbf{. 5 3 3}$ & .867 \\
Statement X2.9 & 26,7333 & 22,809 & $\mathbf{. 8 0 0}$ & .843 \\
\hline
\end{tabular}

Source: Data processed (2020)

From table 6 above the results of the SPSS output, it is known that the validity value is in the Corrected item-total Correlation column, which means the correlation value between the score of each item and the total score on the tabulation of the respondent's answer. The results of the validity test of 9 (nine) questions on the work discipline variable can be declared valid (valid) because all coefficient values are greater than 0.30 . 


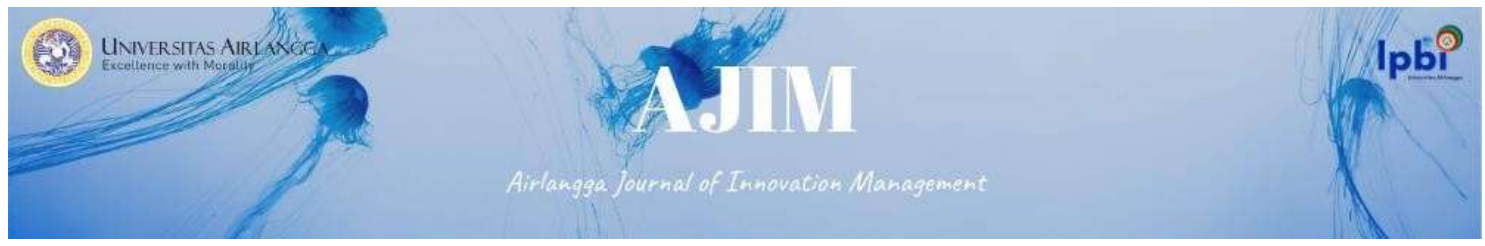

Table 7 Validity Test (Z) Organizational Commitment Item-Total Statistics

\begin{tabular}{|l|r|r|r|r|}
\hline & $\begin{array}{c}\text { Scale Mean if } \\
\text { Item Deleted }\end{array}$ & $\begin{array}{c}\text { Scale Variance if } \\
\text { Item Deleted }\end{array}$ & $\begin{array}{c}\text { Corrected Item- } \\
\text { Total } \\
\text { Correlation }\end{array}$ & $\begin{array}{c}\text { Cronbach's Alpha } \\
\text { if Item Deleted }\end{array}$ \\
\hline Statement Z.1 & 32,2167 & 20,715 & $\mathbf{3 8 2}$ & .743 \\
Statement Z.2 & 31,5000 & 24,017 & $\mathbf{. 3 1 6}$ & .744 \\
Statement Z.3 & 31,6000 & 22,108 & $\mathbf{. 4 1 2}$ & .731 \\
Statement Z.4 & 31,6500 & 19,960 & $\mathbf{. 5 7 9}$ & .701 \\
Statement Z.5 & 31.2833 & 22,342 & $\mathbf{. 5 0 0}$ & .720 \\
Statement Z.6 & 31,8333 & 21,090 & $\mathbf{. 4 6 6}$ & .722 \\
Statement of Z.7 & 31,6500 & 22,299 & $\mathbf{. 5 0 3}$ & .720 \\
Statement of Z.8 & 31.5667 & 21,911 & $\mathbf{. 3 5 9}$ & .742 \\
Statement Z.9 & 31.2333 & 22,995 & $\mathbf{. 4 1 7}$ & .731 \\
\hline
\end{tabular}

Source: Data processed (2020)

From the table 7 above, the results of the SPSS output show that the validity value is in the Corrected item-total Correlation column, which means the correlation value between the score of each item and the total score on the tabulation of the respondent's answer. The results of the validity test of 9 (nine) questions on the organizational commitment variable can be declared valid (valid) because all coefficient values are greater than 0.30 .

Table 8 Validity Test (Y) Employee Performance Item-Total Statistics

\begin{tabular}{|l|r|r|r|r|}
\hline & $\begin{array}{c}\text { Scale Mean if } \\
\text { Item Deleted }\end{array}$ & $\begin{array}{c}\text { Scale Variance if } \\
\text { Item Deleted }\end{array}$ & $\begin{array}{c}\text { Corrected Item- } \\
\text { Total } \\
\text { Correlation }\end{array}$ & $\begin{array}{c}\text { Cronbach's Alpha } \\
\text { if Item Deleted }\end{array}$ \\
\hline Statement Y.1 & 27.2833 & 21,054 & $\mathbf{. 4 7 8}$ & .872 \\
Statement Y.2 & 26,9333 & 18,843 & $\mathbf{. 7 3 3}$ & .849 \\
Statement Y.3 & 26,9833 & 21,813 & $\mathbf{. 3 9 2}$ & .878 \\
Statement Y.4 & 26,9167 & 21,162 & $\mathbf{. 4 9 2}$ & .870 \\
Statement Y.5 & 26.8667 & 18,185 & $\mathbf{. 8 3 4}$ & .839 \\
Statement Y.6 & 27.0167 & 21,373 & $\mathbf{. 4 1 3}$ & .877 \\
Statement Y.7 & 27.0167 & 19,881 & $\mathbf{. 5 8 5}$ & .863 \\
Statement Y.8 & 26,9167 & 18,688 & $\mathbf{. 7 3 3}$ & .849 \\
Statement Y.9 & 26.8667 & 18,185 & $\mathbf{. 8 3 4}$ & .839 \\
\hline
\end{tabular}

Source: Data processed (2020)

From the table 8 above, the results of the SPSS output show that the validity value is in the Corrected item-total Correlation column, which means that the correlation value between the score of each item and the total score on the tabulation of the respondent's answer. The results of the validity test of 9 (nine) questions on the employee performance variable can be declared valid (valid) because all coefficient values are greater than 0.30 .

\section{b. Reliability Testing}

Reliability is the degree of accuracy, precision or accuracy shown by the measurement instrument. Questionnaire items are said to be reliable or reliable if someone's answer to the questionnaire is consistent. In this study, to determine whether the questionnaire was reliable or not, using Cronbach's alpha. The questionnaire is said to be reliable if Cronbach's alpha is $>0.60$ and not reliable if it is equal to or below 0.60 . 


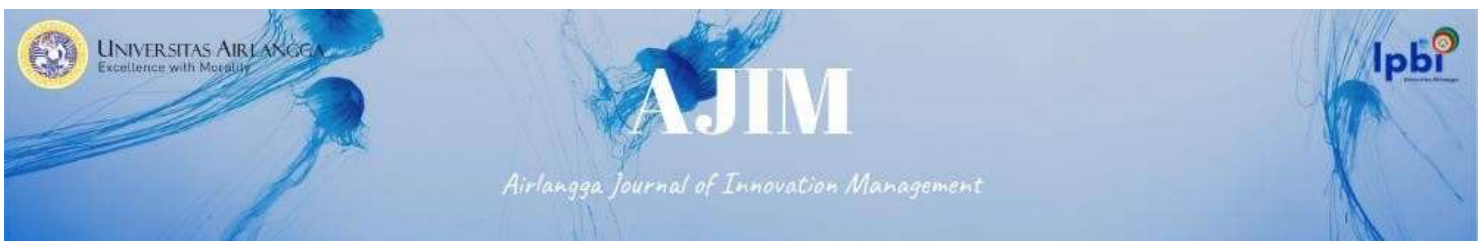

Table 9 Reliability Test (X1) Emotional Intelligence

Reliability Statistics

\begin{tabular}{|r|r|}
\hline Cronbach's Alpha & \multicolumn{2}{|c|}{$\begin{array}{c}\text { N of } \\
\text { Items }\end{array}$} \\
\hline .826 & 9 \\
\hline
\end{tabular}

Source: Data processed (2020)

From the table 9 above, the results of the SPSS output show that the Cronbach's Alpha value is $0.826>0.60$ so it can be concluded that the questions that have been presented to respondents consisting of 9 statements on the emotional intelligence variable are reliable.

Table 10 Reliability Test (X2) Work Discipline

Reliability Statistics

\begin{tabular}{|r|r|}
\hline Cronbach's Alpha & \multicolumn{2}{|c|}{$\begin{array}{c}\text { N of } \\
\text { Items }\end{array}$} \\
\hline .874 & 9 \\
\hline
\end{tabular}

Source: Data processed (2020)

From the table 10 above, the results of the SPSS output show that the Cronbach's Alpha value is $0.874>0.60$ so that it can be concluded that the questions that have been presented to respondents consisting of 9 statements on the work discipline variable are reliable or are said to be reliable.

Table 11 Reliability Test (Z) Organizational Commitment

\section{Reliability Statistics}

\begin{tabular}{|r|r|}
\hline Cronbach's Alpha & N of Items \\
\hline .751 & 9 \\
\hline
\end{tabular}

Source: Data processed (2020)

From the table 11 above, the results of the SPSS output show that the Cronbach's Alpha value is $0.751>0.60$ so it can be concluded that the questions that have been presented to respondents consisting of 9 statement items on the organizational commitment variable are reliable or said to be reliable.

Table 12 Reliability Test (Y) Employee Performance

Reliability Statistics

\begin{tabular}{|r|r|}
\hline Cronbach's Alpha & N of Items \\
\hline .874 & 9 \\
\hline
\end{tabular}

Source: Data processed (2020)

From the table 12 above, the results of the SPSS output show that the Cronbach's Alpha value is $0.874>0.60$ so that it can be concluded that the questions that have been presented to respondents consisting of 9 statements on employee performance variables are reliable. 


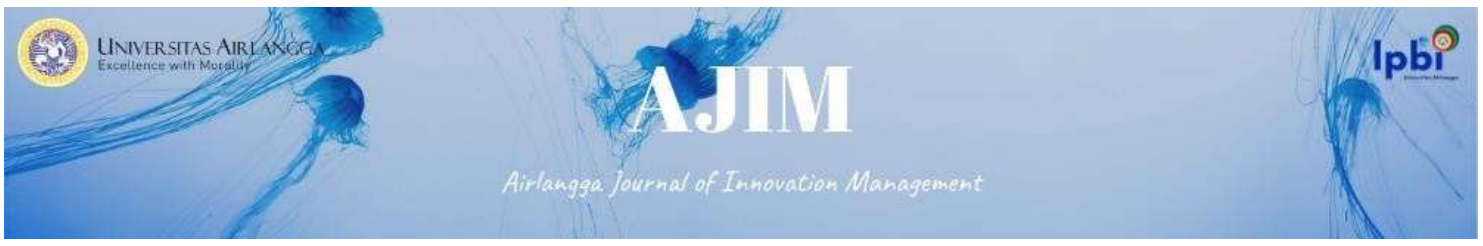

\section{Classic Assumption Testing}

a. Data Normality Test

The normality test aims to test whether in a regression, confounding variables or residuals are normally distributed or not.

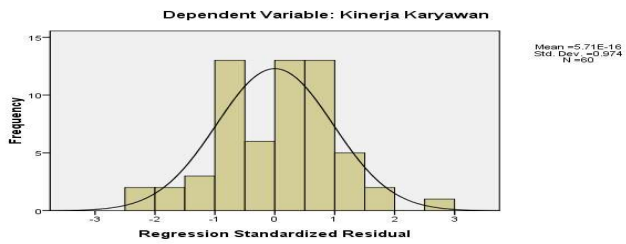

Figure 1 Histogram for Normality Test

Source: Data processed (2020)

Based on Figure 3.1 above, the results of the data normality test show that the data is normally distributed, where the histogram image has a line forming a bell and has a convexity balanced in the middle.

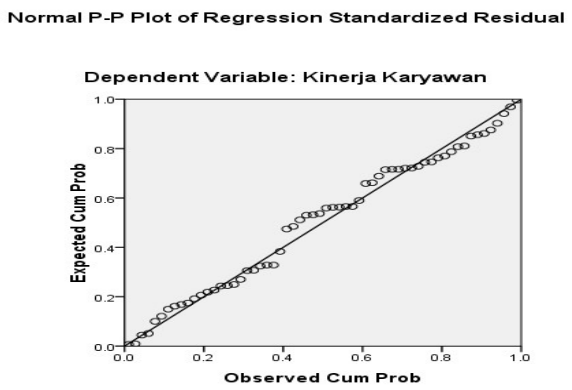

Figure 2 PP Plot Normality Test

Source: Data processed (2020)

Based on Figure 3.2 above, then for the results of data normality testing using the PP Plot image, it can be seen that the scattered data points are around the diagonal line so that the data is normally distributed.

To further ascertain whether the data along the diagonal line is normally distributed or not, the Kolmogorov Smirnov test (1 Sample KS) is carried out by looking at the residual data whether the distribution is normal or not if the value of Asym.sig (2-tailed) $>$ real level $(\alpha=0.05)$ then the residual data is normally distributed. 


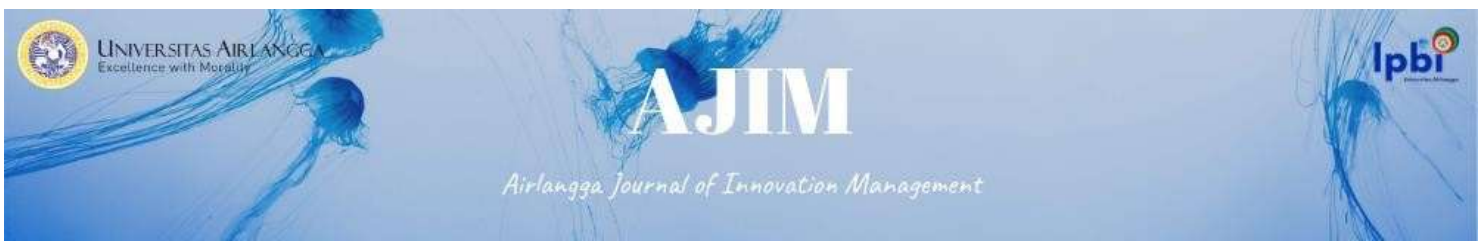

Table 13 Normality Test of One Sample Kolmogorov Smirnov Test One-Sample Kolmogorov-Smirnov Test

\begin{tabular}{|ll|r|}
\hline & & $\begin{array}{c}\text { Unstandardize } \\
\text { d Residual }\end{array}$ \\
\hline $\mathrm{N}$ & Mean & 60 \\
Normal Parameters a & Std. Deviation & .0000000 \\
& Absolute & 2.36570222 \\
Most Extreme Differences & Positive & .081 \\
& Negative & .059 \\
Kolmogorov-Smirnov Z & & -.081 \\
Asymp. Sig. (2-tailed) & & .627 \\
\hline a. Test distribution is Normal. & & $\mathbf{. 8 2 6}$ \\
\hline
\end{tabular}

Source: Data processed (2020)

In table 1.13 above, it can be seen that the results of the data processing, the significance value of the Smirnov Kolmogorov of 0.826 , it can be concluded that the data is normally distributed, where the significance value is greater than $0.05(\mathrm{p}=0.826>0.05)$.

Thus, overall it can be concluded that the observed data values have been normally distributed and can be continued with other classical assumption tests.

b. Multicollinearity Test

The multicollinearity test aims to test whether the regression model found a correlation between independent variables. This test is done by looking at the tolerance value and variance inflation factor (VIF) from the results of the analysis using SPSS. If the tolerance value $>0.10$ or VIF $<10$, it is concluded that there is no multicollinearity.

The multicollinearity test of the questionnaire results that have been distributed to respondents can be seen in the following table.

Table 14 Multicollinearity Test

\begin{tabular}{|c|c|c|c|c|c|c|c|c|}
\hline \multirow{2}{*}{\multicolumn{2}{|c|}{ Model }} & \multicolumn{2}{|c|}{$\begin{array}{l}\text { Unstandardized } \\
\text { Coefficients }\end{array}$} & $\begin{array}{l}\text { Standardized } \\
\text { Coefficients }\end{array}$ & \multirow[b]{2}{*}{$\mathrm{T}$} & \multirow[b]{2}{*}{ Sig. } & \multicolumn{2}{|l|}{$\begin{array}{l}\text { Collinearity } \\
\text { Statistics }\end{array}$} \\
\hline & & B & $\begin{array}{l}\text { Std. } \\
\text { Error }\end{array}$ & Beta & & & Tolerance & IF \\
\hline \multirow[t]{4}{*}{1} & (Constant) & 2,336 & 2,348 & & 995 & 324 & & \\
\hline & Emotional Intelligence & .014 & .093 & .014 & 152 & 000 & .454 & 204 \\
\hline & Work Discipline & .646 & .087 & .237 & ,464 & 000 & .444 & ,252 \\
\hline & $\begin{array}{l}\text { Organizational } \\
\text { Commitment }\end{array}$ & .227 & .077 & .711 & ,944 & 005 & .622 & 609 \\
\hline
\end{tabular}

a. Dependent Variable: Employee Performance

Source: Data processed (2020)

Based on the table 1.14 above, it can be seen that the Variance Inflation Factor (VIF) number is smaller than 10, including emotional intelligence $2.204<10$, work discipline $2.252<10$ and organizational commitment $1.609<10$, and emotional intelligence Tolerance value $0.454>0.10$, work discipline $0.444>0.10$ and organizational commitment $0.622>0.10$ so that it is free from multicollinearity.

c. Heteroscedasticity Test 


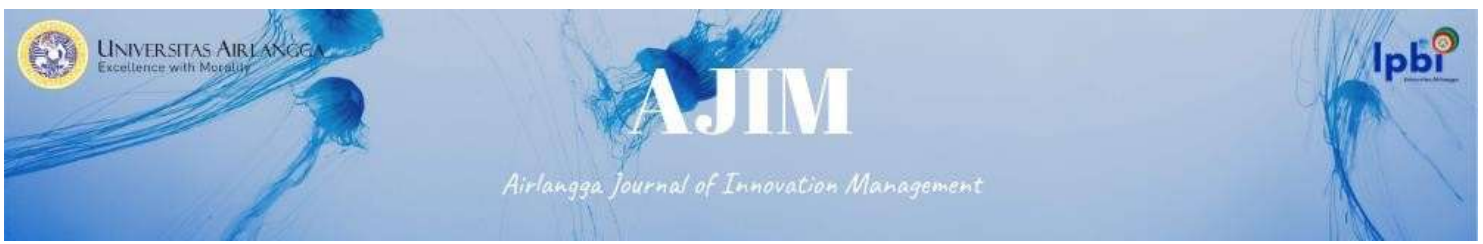

The heteroscedasticity test aims to test whether, in the regression model, there is an inequality of variance from the residuals of one observation to another. A good regression model is one that does not occur heteroscedasticity.

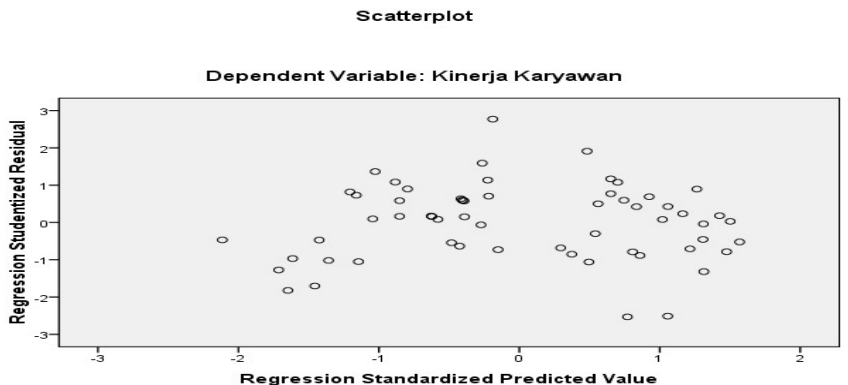

Figure 3 Scatterplot of Heteroscedasticity Test Source: Data processed (2020)

Based on Figure 3.3 above, The scatterplot image shows that the resulting dots spread randomly and do not form a particular pattern or trend line. The image above also shows that the data distribution is around zero points. The results of this test indicate that the regression model is free from heteroscedasticity problems; in other words: the variables to be tested in this study are homoscedasticity.

\section{Test of Conformity (Test Goodness Of Fit)}

a. Simultaneous Significance Test (Test F)

The method used is to look at the level of significance $(=0.05)$. If the significance value is less than 0.05 , then HO is rejected, and Ha is accepted.

Table 15. Simultaneous Test of Organizational Commitment ANOVAb

\begin{tabular}{|c|c|c|c|c|c|}
\hline Model & $\begin{array}{l}\text { Sum of } \\
\text { Squares }\end{array}$ & $\mathrm{df}$ & $\begin{array}{l}\text { Mean } \\
\text { Square }\end{array}$ & $\mathbf{F}$ & Sig. \\
\hline 1 Regression & 601,051 & 2 & 300,525 & 17,344 & $.000 \mathrm{a}$ \\
\hline Residual & 987,683 & 57 & 17,328 & & \\
\hline Total & 1588,733 & 59 & & & \\
\hline
\end{tabular}

a. Predictors: (Constant), Work Discipline, Emotional Intelligence

b. Dependent Variable: Organizational Commitment

Source: Data processed (2020)

Based on table 15 above, it can be seen that F-count is 17.344 while Ftable is 16 , which can be seen at $\alpha=0.05$ (see attachment table F). The significant probability is much smaller than 0.05 , namely $0.001<0.05$, so the regression model can be said that in emotional intelligence research and work discipline simultaneously have a significant effect on organizational commitment. Then the previous hypothesis is Accept Ha, or the hypothesis is accepted. 


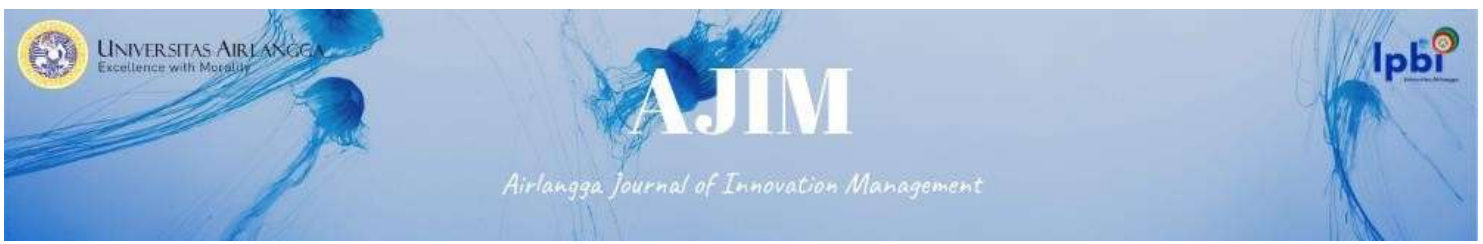

Table 16

Simultaneous Test of Employee Performance ANOVAb

\begin{tabular}{|c|c|c|c|c|c|}
\hline Model & $\begin{array}{l}\text { Sum of } \\
\text { Squares }\end{array}$ & $\mathrm{df}$ & $\begin{array}{l}\text { Mean } \\
\text { Square }\end{array}$ & $\mathbf{F}$ & Sig. \\
\hline 1 Regression & 1133,454 & 3 & 377,818 & 64,076 & $.000 \mathrm{a}$ \\
\hline Residual & 330,196 & 56 & 5,896 & & \\
\hline Total & 1463,650 & 59 & & & \\
\hline
\end{tabular}

a. Predictors: (Constant), Organizational Commitment, Emotional Intelligence, Work Discipline

b. Dependent Variable: Employee Performance

Source: Data processed (2020)

Based on table 16 above, it can be seen that F-count is 64.076 while Ftable is 2.77 , which can be seen at $\alpha=0.05$ (see attachment table F). The significant probability is much smaller than 0.05 , namely $0.000<0.05$, so the regression model can be said that in this study emotional intelligence, work discipline and organizational commitment simultaneously have a significant effect on employee performance. So the previous hypothesis is Accept $\mathrm{Ha}$ (reject $\mathrm{H} 0$ ), or the hypothesis is accepted.

\section{b. Partial Significance Test ( $t$ test)}

Partial test $(\mathrm{t})$ shows how far the independent variables individually explain the variation of this test carried out using a 5\% significance level.

Table 17 Organizational Commitment Partial Test

\section{Coefficientsa}

\begin{tabular}{|c|c|c|c|c|c|c|c|c|}
\hline \multirow{2}{*}{\multicolumn{2}{|c|}{ Model }} & \multicolumn{2}{|c|}{$\begin{array}{l}\text { Unstandardized } \\
\text { Coefficients }\end{array}$} & \multirow{2}{*}{\begin{tabular}{|c}
$\begin{array}{c}\text { Stan } \\
\text { dardized } \\
\text { Coefficients }\end{array}$ \\
Beta \\
\end{tabular}} & \multirow[b]{2}{*}{$\mathrm{t}$} & \multirow[b]{2}{*}{ Sig. } & \multicolumn{2}{|c|}{$\begin{array}{l}\text { Collinearity } \\
\text { Statistics }\end{array}$} \\
\hline & & B & $\begin{array}{l}\text { Std. } \\
\text { Error }\end{array}$ & & & & $\begin{array}{l}\text { Tolera } \\
\text { nce }\end{array}$ & VIF \\
\hline & Constant) & 15,7 & 3,442 & & 4,573 & .000 & & \\
\hline & Emotional Intelligence & .319 & .154 & .309 & 2,069 & .043 & .488 & 2,050 \\
\hline & Work Discipline & .336 & .142 & .354 & 2,370 & .021 & .488 & 2,050 \\
\hline
\end{tabular}

a. Dependent Variable: Organizational Commitment

Source: Data processed (2020)

Based on table 1.17 above, it can be seen that:

1) The influence of emotional intelligence on organizational commitment.

Significant testing with decision-making criteria:

$\mathrm{Ha}$ is accepted and $\mathrm{HO}$ is rejected if $\mathrm{t}_{\text {-count }}>\mathrm{t}$ table or Sig. $\mathrm{t}<\alpha$

$\mathrm{Ha}$ is rejected, and $\mathrm{H} 0$ is accepted, if $\mathrm{t}_{\text {-count }}<\mathrm{t}$ table or Sig. $\mathrm{t}>\alpha$

$\mathrm{t}$ count is 2.069 while $\mathrm{t}$ table is 2.002 and significant is 0.043 , so tcount $2.069>\mathrm{t}$ table 2.002 and significant $0.043<0.05$, then $\mathrm{Ha}$ is accepted and $\mathrm{H} 0$ is rejected, which states emotional intelligence partially significant effect on organizational commitment.

2) The influence of work discipline on organizational commitment.

Significant testing with decision-making criteria:

$\mathrm{Ha}$ is accepted and $\mathrm{H} 0$ is rejected if $\mathrm{t}_{\text {-count }}>\mathrm{t}$ table or Sig. $\mathrm{t}<\alpha$

$\mathrm{Ha}$ is rejected, and $\mathrm{H} 0$ is accepted, if $\mathrm{t}_{\text {-count }}<\mathrm{t}$ table or Sig. $\mathrm{t}>\alpha$ 


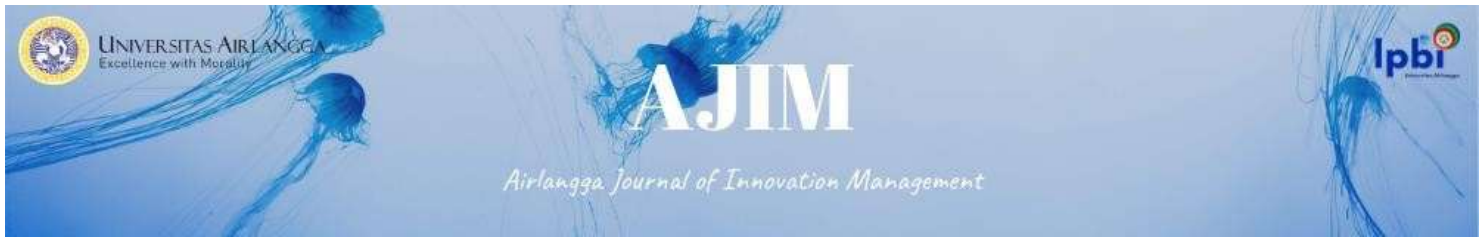

$\mathrm{t}$ count is 2,370 while $\mathrm{t}$ table is 2,002 and significant is 0,021 , so $\mathrm{t}$ count $2,370>\mathrm{t}$ table 2,002 and significant $0,021<0,05$, so $\mathrm{Ha}$ is accepted and $\mathrm{H} 0$ is rejected, which states that work discipline partially significant effect on organizational commitment.

Table 18 Partial Test of Employee Performance

Coefficientsa

\begin{tabular}{|c|c|c|c|c|c|c|c|}
\hline \multirow[b]{2}{*}{ Model } & \multicolumn{2}{|c|}{$\begin{array}{l}\text { Unstandardized } \\
\text { Coefficients }\end{array}$} & $\begin{array}{l}\text { Standardized } \\
\text { Coefficients }\end{array}$ & \multirow[b]{2}{*}{$\mathrm{T}$} & \multirow[b]{2}{*}{ Sig. } & \multicolumn{2}{|l|}{$\begin{array}{l}\text { Collinearity } \\
\text { Statistics }\end{array}$} \\
\hline & B & $\begin{array}{l}\text { Std. } \\
\text { Error }\end{array}$ & Beta & & & Tolerance & IF \\
\hline 1 (Constant) & 2,336 & 2,348 & & .995 & .324 & & \\
\hline Emotional Intelligence & .014 & .093 & .014 & 7,152 & .000 & .454 & 2,204 \\
\hline Work Discipline & .646 & .087 & .237 & 7,464 & .000 & .444 & 2,252 \\
\hline $\begin{array}{l}\text { Organizational } \\
\text { Commitment }\end{array}$ & .227 & .077 & .711 & 2,944 & .005 & .622 & 1,609 \\
\hline
\end{tabular}

Performance

Source: Data processed (2020)

Based on the table 18 above, it can be seen that:

1) The influence of emotional intelligence on employee performance.

Significant testing with decision-making criteria:

$\mathrm{Ha}$ is accepted and $\mathrm{H} 0$ is rejected, if $\mathrm{t}_{\text {count }}>\mathrm{t}$ table or Sig. $\mathrm{t}<\alpha$

$\mathrm{Ha}$ is rejected and $\mathrm{H} 0$ is accepted, if $\mathrm{t}_{\text {count }}<\mathrm{t}$ table or Sig. $\mathrm{t}>\alpha$

$\mathrm{t}$ count is 7,152 while $\mathrm{t}$ table is 2,003 and significant is 0,000 , so tcount $7,152>$ ttable 2,003 and significant $0,000<0,05$, then $\mathrm{Ha}$ is accepted and $\mathrm{H} 0$ is rejected, which states emotional intelligence has a partially significant effect on employee performance.

2) Effect of work discipline on employee performance.

Significant testing with decision-making criteria:

$\mathrm{Ha}$ is accepted and $\mathrm{H} 0$ is rejected, if $\mathrm{t}_{\text {-count }}>\mathrm{t}$ table or Sig. $\mathrm{t}<\alpha$

$\mathrm{Ha}$ is rejected and $\mathrm{H} 0$ is accepted, if $\mathrm{t}_{\text {-count }}<\mathrm{t}$ table or Sig. $\mathrm{t}>\alpha$

$\mathrm{t}$ count is 7,464 while $\mathrm{t}$ table is 2,003 and significant is 0,000 , so tcount 7,464>t table 2,003 and significant $0,000<0,05$, then $\mathrm{Ha}$ is accepted and $\mathrm{H} 0$ is rejected, which states that work discipline partially significant effect on employee performance.

3) The influence of organizational commitment on employee performance.

Significant testing with decision-making criteria:

$\mathrm{Ha}$ is accepted and $\mathrm{H} 0$ is rejected if $\mathrm{t}_{\text {-count }}>\mathrm{t}$ table or Sig. $\mathrm{t}<\alpha$

$\mathrm{Ha}$ is rejected and $\mathrm{H} 0$ is accepted, if $\mathrm{t}_{\text {-count }}<\mathrm{t}$ table or Sig. $\mathrm{t}>\alpha$

$\mathrm{t}$ count is 2,944 while $\mathrm{t}$ table is 2,003 and significant is 0,005 , so tcount is $2,944>\mathrm{t}$ table is 2,003 and significant is $0,005<0,05$, then $\mathrm{Ha}$ is accepted and $\mathrm{H} 0$ is rejected, which states that organizational commitment has a partially significant effect on employee performance.

\section{c. Coefficient of Determination}

Analysis of the coefficient of determination is used to determine the percentage of the variation in the influence of independent variables on the dependent variable. 


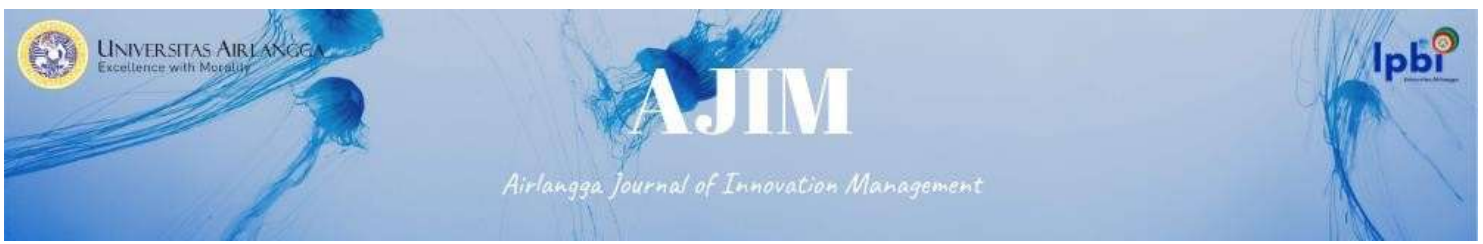

Table 19 Coefficient of Determination

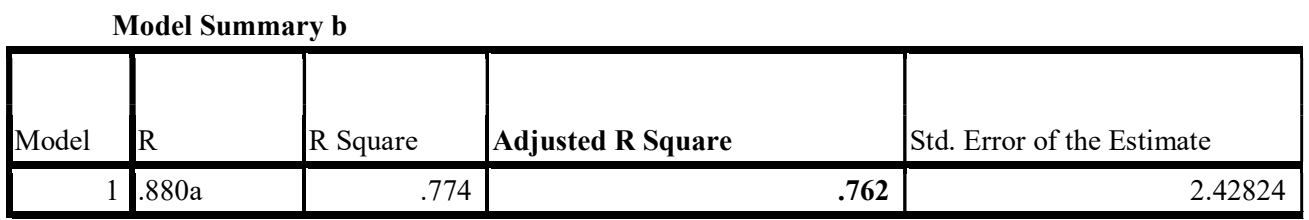

a. Predictors: (Constant), Organizational Commitment, Emotional Intelligence, Work Discipline

b. Dependent Variable: Employee Performance

Source: Data processed (2020)

Based on table 19 above, it can be seen that the Adjusted R Square figure is 0.762 which can be called the coefficient of determination, which in this case means $76.2 \%$ of employee performance can be obtained and explained by emotional intelligence, work discipline and organizational commitment. In comparison, the remaining $100 \%-76.2 \%=23.8 \%$ is explained by other factors or variables outside the model, such as training, wages, leadership style and others.

\section{Path Analysis}

Table 20. Path Analysis of Equation I

\begin{tabular}{|c|c|c|c|c|c|c|c|c|}
\hline & \multirow[b]{2}{*}{ Model } & \multicolumn{2}{|c|}{$\begin{array}{l}\text { Unstandardized } \\
\text { Coefficients }\end{array}$} & $\begin{array}{l}\text { Standardized } \\
\text { Coefficients }\end{array}$ & \multirow[b]{2}{*}{$\mathrm{T}$} & \multirow[b]{2}{*}{ Sig. } & \multicolumn{2}{|c|}{$\begin{array}{l}\text { Collinearity } \\
\text { Statistics }\end{array}$} \\
\hline & & B & $\begin{array}{l}\text { Std. } \\
\text { Error }\end{array}$ & Beta & & & Tolerance & IF \\
\hline \multirow[t]{3}{*}{1} & (Constant) & 15,742 & 3,442 & &, 573 & 000 & & \\
\hline & Emotional Intelligence & .319 & .154 & .309 &, 069 & .043 & .488 &, 050 \\
\hline & Work Discipline & .336 & .142 & .354 &, 370 & 021 & 488 & 2,050 \\
\hline
\end{tabular}

Commitment

Dependent Variable:

Organizational

Model Summary b

\begin{tabular}{|l|r|r|r|r|}
\hline Model & $\mathrm{R}$ & R Square & \multicolumn{1}{|c|}{$\begin{array}{c}\text { Adjusted R } \\
\text { Square }\end{array}$} & Std. Error of the Estimate \\
\hline 1 & $.615 \mathrm{a}$ & .378 & $\mathbf{3 5 7}$ & 4.16266 \\
\hline
\end{tabular}

a. Predictors: (Constant), Work Discipline, Emotional Intelligence

b. Dependent Variable: Organizational Commitment

Source: Data processed (2020)

Based on the table 20 above, the standardized beta value for emotional intelligence is 0.309 and significant at 0.043 , which means that emotional intelligence affects organizational commitment. The standardized beta coefficient value 0.309 is the path value or path P1. The standardized beta value for work discipline is 0.354 and is significant at 0.021 , which means that work discipline affects organizational commitment. The standardized beta coefficient value of 0.354 is the path value or path P1. The value of e $1=(1-0.357) 2=0.4134$.

Equation I: $\mathrm{Z}=0.309 \mathrm{X} 1+0.354 \mathrm{X} 2+0.4134 €_{1}$ 


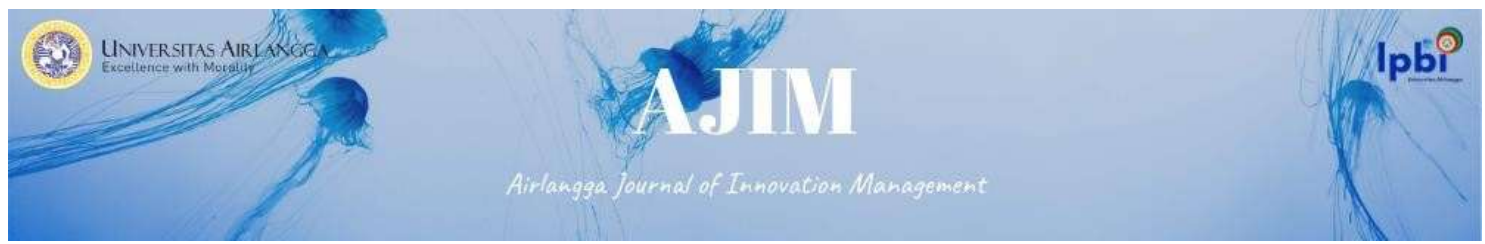

Table 21. Path Analysis of Equation II

Coefficientsa

\begin{tabular}{|c|c|c|c|c|c|c|c|}
\hline \multirow[b]{2}{*}{ Model } & \multicolumn{2}{|c|}{$\begin{array}{l}\text { Unstandardized } \\
\text { Coefficients }\end{array}$} & $\begin{array}{l}\text { Standardized } \\
\text { Coefficients }\end{array}$ & \multirow[b]{2}{*}{$\mathrm{t}$} & \multirow[b]{2}{*}{ ig. } & \multicolumn{2}{|c|}{$\begin{array}{l}\text { Collinearity } \\
\text { Statistics }\end{array}$} \\
\hline & B & $\begin{array}{r}\text { St } \\
\text { d. Error }\end{array}$ & Beta & & & $\begin{array}{c}\text { oleranc }^{\mathrm{T}} \\
\mathrm{e}\end{array}$ & IF \\
\hline (Constant) & 2,336 & 2,348 & & .995 & 324 & & \\
\hline $\begin{array}{l}\text { Emotional } \\
\text { Intelligence }\end{array}$ & .014 & .093 & .014 & 7,152 & .000 & .454 & 2,204 \\
\hline Work Discipline & .646 & .087 & .237 & 7,464 & 000 & .444 & 2,252 \\
\hline $\begin{array}{l}\text { Organizational } \\
\text { Commitment }\end{array}$ & .227 & .077 & .711 & 2,944 & .005 & .622 & 1,609 \\
\hline
\end{tabular}

Employee Performance

Source: Data processed (2020)

Model Summary b

\begin{tabular}{|r|l|r|r|l|}
\hline Model & $\mathrm{R}$ & R Square & Adjusted R Square & $\begin{array}{l}\text { Std. Error of the } \\
\text { Estimate }\end{array}$ \\
\hline 1 & $.880 \mathrm{a}$ & .774 & $\mathbf{. 7 6 2}$ & \multicolumn{2}{|c|}{2.42824} \\
\hline
\end{tabular}

a. Predictors: (Constant), Organizational Commitment, Emotional Intelligence, Work Discipline

b. Dependent Variable: Employee

Performance

Source: Data processed (2020)

Based on table 21 above, the standardized beta value for emotional intelligence is 0.014 and significant at 0.000 , which means that emotional intelligence affects employee performance. The standardized beta coefficient value of 0.014 is the path value or path P3. The standardized beta value for work discipline is 0.237 and is significant at 0.000 , which means that work discipline affects employee performance. The standardized beta coefficient value 0.237 is the path value or path $\mathrm{P} 3$. The standardized beta value for organizational commitment is 0.711 and significant at 0.005 , which means that organizational commitment affects employee performance. The standardized beta coefficient value 0.711 is the path value or path $\mathrm{P} 2$.

The value of $\mathrm{e} 2=(1-0.762) 2=0.0566$.

Equation II: $\mathrm{Y}=0.014 \mathrm{X} 1+0.237 \mathrm{X} 2+0.711 \mathrm{Z}+0.0566 €_{2}$ 

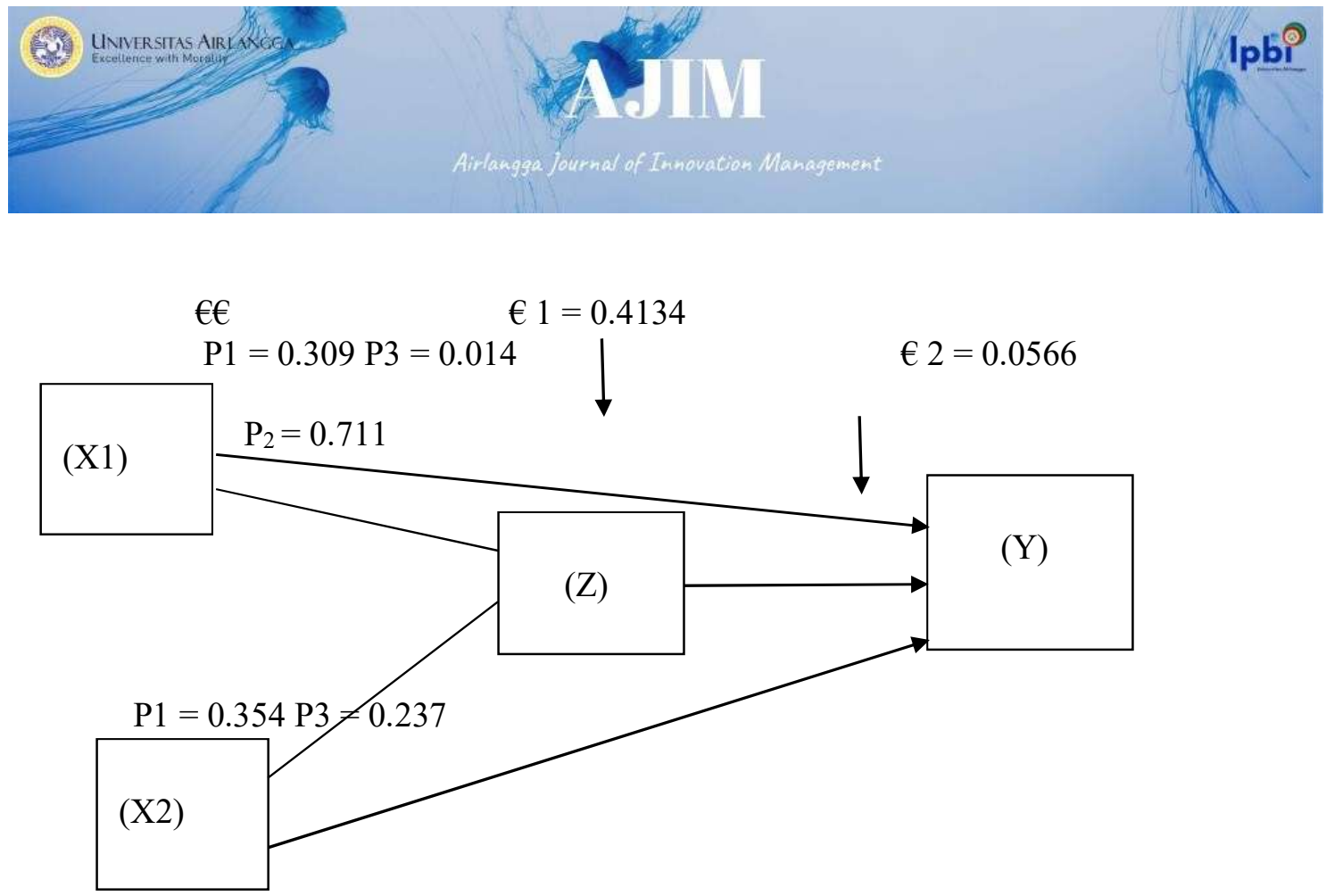

Figure 4 Path Analysis

Source: Data processed (2020)

\section{Mediation Test}

a. The influence of emotional intelligence on employee performance with organizational work commitment becomes an intervening variable.

Based on Figure 4.4 above, the path analysis results show that emotional intelligence has a direct effect on employee performance and can also have an indirect effect, namely from the effect of emotional intelligence to organizational commitment (as an intervening variable) to employee performance. The amount of direct influence is 0.014 , while the size of the indirect effect must be calculated by multiplying the indirect coefficient, namely $0.309 \times 0.711=0.219$ or the total effect of emotional intelligence on employee performance $=0.014+(0.309 \times 0.711)=0.233$. Because of the value ( $\mathrm{P} 3<\mathrm{P} 1 \times \mathrm{P} 2)$, organizational commitment functions as an intervening variable.

b. The influence of work discipline on employee performance with organizational commitment becomes an intervening variable.

Based on Figure 4.4 above, the results of the path analysis show that work discipline has a direct effect on employee performance and can also have an indirect effect, namely from the effect of work discipline to organizational commitment (as an intervening variable) to employee performance. The magnitude of the direct effect is 0.237 , while the amount of the indirect effect must be calculated by multiplying the indirect coefficient, namely $0.354 \times 0.711=0.251$ or the total effect of work discipline on employee performance $=0.237+(0.354 \times 0.711)=0.488$. Because of the value $(\mathrm{P} 3<\mathrm{P} 1$ $\mathrm{x}$ P2), organizational commitment functions as an intervening variable.

\section{B. Discussion}

1. The Effect of Emotional Intelligence on Employee Performance

The results show that emotional intelligence has a positive and significant effect on employee performance, where tcount 7,152> ttable 2,003 and significant $0,000<0.05$, then $\mathrm{Ha}$ is accepted and $\mathrm{H} 0$ is rejected. The results of this study are consistent with the research of Susandi (2017), Sudewi (2017), Hassan (2016), Sarawati (2014) and Ahmed (2016), that emotional intelligence has a positive and significant effect on employee performance. According to Goleman (2014: 75), employees who have high emotional intelligence will produce better performance which can be seen from the quality and quantity given to the company by these employees. Goleman (2014: 76) also revealed that even if 


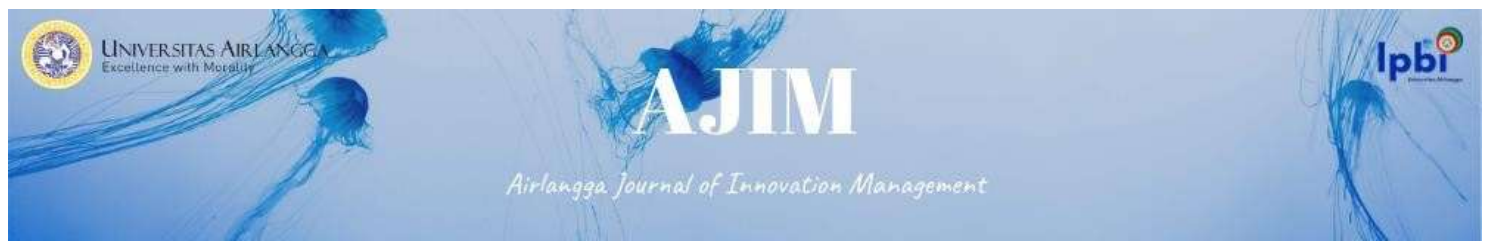

someone has a pretty good performance, if he has a closed nature and does not interact well with other people, his performance will not be able to develop.

2. The Effect of Work Discipline on Employee Performance

The results show that work discipline has a positive and significant effect on employee performance, where tcount 7,464> ttable 2,003 and significant $0,000<0.05$, then $\mathrm{Ha}$ is accepted and $\mathrm{H} 0$ is rejected. The results of this study are in accordance with Susandi's research (2017) where "work discipline has a positive and significant effect on employee performance". The implementation of discipline in a company is a must because discipline is used as a rule or guideline in managing company management. This also support Rivai (2013: 825) that discipline is a tool used by managers to communicate with employees so that they are willing to change a behavior and as an effort to increase one's awareness and willingness to obey all applicable social rules and norms. Discipline looks at how employee compliance is to be able to obey and orderly carry out existing rules, assess knowledge of applicable regulations, and self-awareness. Discipline itself is one of the factors that affect the level of performance possessed by employees. Employee compliance in implementing work discipline will help improve employee performance in carrying out work discipline and ensure the smooth and smooth implementation of company operations.

\section{The Effect of Emotional Intelligence on Employee Performance with Organizational} Commitment as an Intervening Variable

The results show that emotional intelligence has a direct effect on employee performance and can also have an indirect effect, namely from the effect of emotional intelligence to organizational commitment (as an intervening variable) then to employee performance. The amount of direct influence is 0.014 , while the size of the indirect effect must be calculated by multiplying the indirect coefficient, namely $0.309 \times 0.711=0.219$ or the total effect of emotional intelligence on employee performance $=$ $0.014+(0.309 \times 0.711)=0.233$. Because of the value $(\mathrm{P} 3<\mathrm{P} 1 \times \mathrm{P} 2)$, organizational commitment functions as an intervening variable.

4. The Effect of Work Discipline on Employee Performance with Organizational Commitment as an Intervening Variable

The results show that work discipline has a direct effect on employee performance and can also have an indirect effect, namely from the influence of work discipline to organizational commitment (as an intervening variable) then to employee performance. The magnitude of the direct effect is 0.237 , while the amount of the indirect effect must be calculated by multiplying the indirect coefficient, namely $0.354 \times 0.711=0.251$ or the total effect of work discipline on employee performance $=0.237+(0.354$ $\mathrm{x} 0.711)=0.488$. Because of the value $(\mathrm{P} 3<\mathrm{P} 1 \times \mathrm{P} 2)$, organizational commitment functions as an intervening variable.

\section{CONCLUSIONS AND SUGGESTIONS}

\section{Conclusion}

Based on the results of the data analysis that has been carried out, it can be concluded as follows:

1. Partial emotional intelligence positive and significant effect to employee performance at PT JTI, where tcount 7,152> ttable 2,003 and significant $0,000<0,05$.

2. Work discipline partially positive and significant effect to employee performance at PT JTI, where where tcount 7,464> ttable 2,003 and significant $0,000<0,05$.

3. Emotional intelligencetake effect to employee performance with through organizational commitment at PT JTI, where The magnitude of the direct effect is 0.014 , while the size of the indirect effect must be calculated by multiplying the indirect coefficient, namely $0.309 \times 0.711$ $=0.219$ or the total effect of emotional intelligence on employee performance $=0.014+(0.309$ $\mathrm{x} 0.711)=0.233$. Because of the value $(\mathrm{P} 3<\mathrm{P} 1 \mathrm{x} \mathrm{P} 2)$, organizational commitment functions as an intervening variable. 


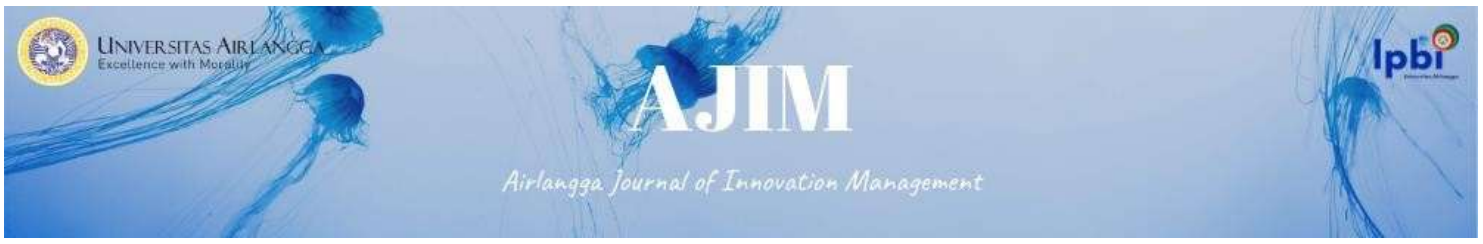

4. Work disciplinetake effect to employee performance with through organizational commitment at PT JTI, where the magnitude of the direct effect is 0.237 , while the size of the indirect effect must be calculated by multiplying the indirect coefficient, namely $0.354 \times 0.711=0.251$ or the total effect of work discipline on employee performance $=0.237+(0.354 \times 0.711)=0.488$. Because of the value $(\mathrm{P} 3<\mathrm{P} 1 \times \mathrm{P} 2)$, organizational commitment functions as an intervening variable.

\section{B. Suggestion}

Based on the results of the research, the authors put forward the following suggestions:

1. It is hoped that employees will change their negative outlook on things that are positive and make sense, so that these views can improve the employee's performance.

2. It is expected that employees always maintain a good attitude towards other employees and also comply with the existing regulations at PT JTI so that employee performance can increase.

3. Companies need to increase organizational commitment by creating a desire to be part of the organization, proud of the organization, caring about the organization and wanting to work for the organization for a long time.

\section{REFERENCES}

Al Jerjawi, K. (2016). Cultural dimensions' impact on performance management in the UAE market. Innovative Journal of Business and Management, 5(3), 62-71.

Assari, H., Safi, V., \& Assari, M. (2016). An evaluation on the relation of organizational commitment and knowledge sharing a case study: Trade Ministry Rahbar Informatics Service Co. Mediterranean Journal of Social Sciences, 7(5 S1), 111. DOI:10.5901/mjss.2016.v7n51p111

Bezzina, C. (2006). "The Road Less Traveled": Professional communities in secondary schools. Theory into Practice, 45(2), 159-167. DOI:10.1207/s15430421tip4502_8

Borman, W. C., \& Motowidlo, S. J. (1997). Task performance and contextual performance: The meaning for personnel selection research. Human Performance, 10(2), 99-109.

Bowman, T. G., Mazerolle, S. M., \& Dodge, T. M. (2016). Retention initiatives used by professional bachelor's athletic training program directors. Athletic Training Education Journal, 11(1), 18-26. DOI: $10.4085 / 110118$

Cetin, S., Gurbuz, S., \& Sert, M. (2015). A meta-analysis of the relationship between organizational commitment and organizational citizenship behavior: Test of potential moderator variables. Employee Responsibilities and Rights Journal, 27(4), 281-303. DOI:10.1007/s10672-015-92665

Dul, J. (2016). Necessary condition analysis (NCA) logic and methodology of "Necessary but Not Sufficient" causality. Organizational Research Methods, 19(1), 10-52. DOI:10.1177/ 1094428115584005

Morrow PC. (1983). Concept redundancy in organizational research: the case of work commitment. Acad Manag Rev. 8(3):486 -500.

Meyer JP, Allen, NJ. (1991). A three-component conceptualization of organizational commitment. Hum Resour Manag Rev. 1(1):61 -89.

Naz G, Ali A, Afzal I, Zia-ur-rehman (2012). Developing and testing a model of antecedents and consequences of organization commitment. Glob J Manag Bus Res. 12(13):44 -54.

N Setiawan. (2012). Pengaruh Performance, Orientasi Dan Pengembangan Karir Terhadap Produktivitas Kerja Pada Pt. Gudang Garam Tbk. Cabang Medan. Dunia Ilmu.

N Setiawan, E Wakhyuni, A Setiawan (2019). The Analysis Of Management Information Systems And Decision Making On Employee Performance At Pt" G" Parking Medan, Multi-Disciplinary International Conference University of Asahan. 


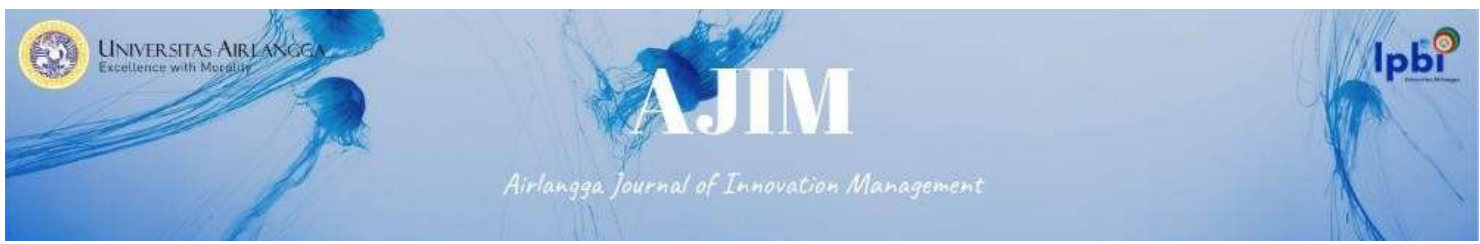

Porter LW, Steers RM, Boulian PV. (1974). Organizational commitment, job satisfaction and turnover among psychiatric technicians. J Appl Psychol. 59:603 -9.

Rhoades, L., \& Eisenberger, R. (2002). Perceived organizational support: a review of the literature. Journal of applied psychology, 87(4), 698.

Reichers AE. (1985). A review and reconceptualization of organizational commitment. Acad Manag Rev. 10:465-76.

Robbins, S. P., \& Coulter, M. in E. Cliffs. (2001). Management. NY: Prentice Hall.

Robbins, S. P., Judge, T. A., \& Vohra, N. (1996). Organizational Behavior. NY: Prentice Hall.

Tufail M, Zia YA, Khan S, Irfan M. (2012). A Glance at organizational commitment, antecedents and consequences (1960-2005). J Manag Sci. 6(1):73 -91.

Stinglhamber, F. D. (2006). Perceived Support as a Mediator of the Relationship Between Justice and Trust A Multiple Foci Approach. Group \& Organization Management, 442-468.

Thibaut, J., \& Walker, L. (1975). Procedural justice: A psychological analysis.

Vandenberghe, C. a. (2008). The role of pay satisfaction and organizational commitment in turnover intentions: A two-sample study. Journal of Business and psychology, 275-286.

Wayne, S., Shore, J., L, M., \& Liden, R. C. (1997). Perceived organizational support and leader-member exchange: A social exchange perspective. Academy of Management journal, 40(1), 82-110.

Whitener, E. (1997). The impact of human resource activities on employee trust. Human Resource Management Review, 389-404. 